\title{
Factors Affecting the Housing Affordability of Homebuyers in Perak: Measuring Transport Expenditure
}

\author{
Norhayati BAHARUN, Suraya MASROM and Afiqah ROSHIDI
}

Faculty of Computer \& Mathematical Sciences, Universiti Teknologi MARA Perak Branch, Tapah Campus, Tapah Road, Perak Darul Ridzuan, Malaysia

Correspondence should be addressed to: Norhayati BAHARUN; norha603@uitm.edu.my

Received date:11 August 2020; Accepted date:3 February 2021; Published date: $1^{\text {st }}$ September 2021

Academic Editor: HISHAMUDDIN MOHD ALI

Copyright (C) 2021. Norhayati BAHARUN, Suraya MASROM and Afiqah ROSHIDI. Distributed under Creative Commons Attribution 4.0 International CC-BY 4.0

\begin{abstract}
Increasing housing prices in Perak has made it difficult for homebuyers to own affordable housing. Housing affordability ensures that housing provided is affordable for every income group, especially the low and middle-income groups. It has brought the government and housing developers' attention the issue of housing affordability by supplying public low-cost housing schemes. The traditional measurement of housing affordability is by using the percentage of household income spent on housing. The important cost that is usually ignored in measuring housing affordability is transportation costs. Housing and transportation are the two largest expenses for most households. This paper aims to determine the factors affecting housing affordability by including transportation expenditures. A total of 65 questionnaires were distributed to the homebuyers in Perak Tengah. The multiple linear regression was conducted, and the results revealed that locational, neighborhood, structural and financial were significant factors influencing housing affordability. It also showed that including transportation expenditure into the calculation of housing affordability can reveal true housing affordability measurement.
\end{abstract}

Keywords: Housing affordability, locational, neighborhood, structural, financial, transportation expenditure.

Cite this Article as: Norhayati BAHARUN, Suraya MASROM and Afiqah ROSHIDI (2021), "Factors Affecting the Housing Affordability of Homebuyers in Perak: Measuring Transport Expenditure", Journal of Southeast Asian Research, Vol. 2021 (2021), Article ID 676983, DOI: 10.5171/2021.676983 


\section{Introduction}

Affordability concerns making housing affordable for every household, however, it is not meant to focus only on the low prices, but also on the quality of the house. The government is responsible for providing housing for low-income households. However, private sectors have concentrated on high-end houses due to the significant increase in house and land prices. To provide affordable and quality housing, it is important to identify the main factors that influence people to buy houses such as housing prices and location. Housing affordability is a crucial issue over the last decade because of the continuous increase in property prices due to the economic rapid growth. This is because the house price is the main consideration when deciding to own a house. Housing prices within an urban area in Malaysia are becoming severely unaffordable as compared to housing in rural areas. Housing prices are highly dependent on location since location plays important role in the housing market. Location has also become the main consideration when purchasing a residential property, especially the distance between residential neighborhoods and employment centers. Housing is not truly affordable if located in an accessible area with high transportation costs. This is because the transportation costs are highly associated with the selection of the residential location.

A significant number of previous research on housing affordability has been focusing on housing costs and household income. Recently, there is a new indicator of housing affordability which includes transportation expenditure (Yusoff et al., 2014). This is because housing and transportation are the two largest expenses for most households. Previous housing affordability studies generally ignore the dimensions of transportation cost even though there is a strong influence on household expenditure (Mattingly and Morrissey, 2014). However, research by Dewita et al. (2018) mentioned that incorporating transportation costs into housing affordability measurements reveals a different pattern of affordability. There has been little research to investigate how the combination of housing and transportation costs can impact housing affordability measurements. Therefore, this study seeks to measure housing affordability by considering not only the cost of housing but the condition and location efficiency by measuring transportation costs.

\section{Literature Review}

\section{Housing Affordability}

Recently, researchers have changed their perspectives about the traditional way of defining the measurement of housing affordability. Research in the USA suggests that housing may be considered affordable in terms of the price of the house related to the annual household income, however, transportation costs are often underestimated or ignored (Mulliner and Maliene, 2012). The research stated that the interaction between housing and transportation costs provides a more meaningful measurement of housing affordability. Affordability is the ability of the person to provide something, that is usually referred to as the ability in financial terms. The various definitions and concepts of housing affordability give different approaches to measure housing affordability such as price to income ratio, residual income, and purchase and repayment affordability (Gan and Hill, 2009). Purchase affordability refers to the ability of the household to borrow enough funds to purchase a house. Repayment affordability refers to the burden on the household to pay the mortgage while income affordability refers to the measurement of the ratio of house prices to the income of the purchaser. Besides, housing affordability is defined as the condition in which people have the potential to save a certain portion of income to buy the house as well as other consumptions (Mostafa et al., 2006). In Malaysia, housing affordability is denoted as the rent-to-income ratio or house price-toincome ratio known as income affordability. The median multiple is a common measurement suggested by the World Bank 
and the United Nations which rates the affordability of housing by dividing the median house price and annual median household income.

\section{Housing Attributes}

Housing preferences will be determined by a set of various attributes of housing households (Tan and Cheah, 2013). Housing attributes have been shown in previous research as major factors influencing housing affordability such as structural, location, and neighborhood of housing.

Location attributes are highly related to the area or place where the housing is located, whether an urban area or a rural area. The distance is considered as the main factor that affects the buyer's preference in decision making, such as distance to workplace, schools, shops, and other facilities (Sean and Hong, 2014). Daly et al. (2003) mentioned that location has a primary impact on the buyer's preference in purchasing residential properties in Australia, UK, and Ireland. Besides, Kauko (2007) stated that location is an important factor to determines the success or failure of the residential housing project. Natasha and Hassan (2015) found that location attributes have a positive relationship and can have a positive impact on the intention to make a property investment. Location was considered the highest contribution that influences the housing price (Olanrewaju et al., 2018).

Neighborhood is also one of the most important attributes to measure housing affordability. According to Sean and Hong (2014), neighborhood is defined as the area in which residents live together for the common interest. Previous research by Zrobek et al. (2015) has shown that cleanliness and low crime trends are examples of good neighborhood environments that are important aspects of purchasing residential properties. A good neighborhood has a positive impact on housing prices. According to Teck-Hong (2011), a house in a good neighborhood is preferred, as households are willing to pay extra for a house of good environmental quality. Thaker and Sakaran (2016) mentioned that the good quality of a residential property can be valued by an excellent indoor and outdoor environment. Besides, Thanaraju et al. (2019) mentioned that the safety of the neighborhood is also considered as another important aspect when purchasing a residential property. This is because of the increase in the trend of crimes such as burglary and snatch. Besides, the security of the neighborhood is very important for the safety level of the residential area since the number of crimes in Malaysia is increasing (Mariadas et al.,2019).

Numerous empirical studies have identified structural attributes as influential components of households' in the housebuying decision. According to (Teck-Hong, 2012), structural attributes that can impact home-buying preferences include lot size, the number of bedrooms and bathrooms, and the presence of a garden in the house. Hurtubia et al. (2010) mentioned that the number of bedrooms and bathrooms in a house is an important aspect to be considered when purchasing a residential property. For instance, in Saudi Arabia, private living spaces such as the number and the size of bedrooms, and the number of bathrooms are considered to be important factors because they are directly related to the problem of privacy (Opoku and AbdulMuhmin, 2010). A similar finding by Chia et al. (2016) concluded that a private living space is considered to be a key housing attribute because it can be directly related to the issue of privacy. Besides, Sundrani (2018) also mentioned that the number and the size of bedrooms are the most important features to be considered in homeownership decisions.

Financial attributes are important features that should be considered by the households in their homeownership decisions. Moreover, financial attributes strongly influence the decision of homebuyers to purchase a residential property (Sean and Hong, 2014; Thaker and Sakaran, 2016). As mentioned by Mariadas et al. (2019), there are several key areas regarding financial considerations such as interest rate, house price, household income, and the ability to obtain financing. 
Li et al. (2014) also mentioned that financial factors such as length of the period for the payment, interest rate, and the amount of monthly payment are the main considerations while choosing a residential property to purchase. Zainon et al. (2017) concluded that the financial factor has a positive influence on housing affordability.

\section{Transport Expenditure}

In recent years, there is a new indicator of housing affordability that includes transport expenditure (Sabri et al., 2013; Yusoff et al., 2014). Housing and transportation are the two largest expenses for most households. Besides, housing and transport expenditures show a more complete picture of affordability in the neighborhood. The traditional measure of housing affordability generally focused on housing cost alone, while ignored the transportation cost which incurs a relatively high proportion of income. Therefore, combining housing and transportation cost offers an expanded view of affordability. Previous research suggested that incorporating transportation costs into housing affordability calculations can reveal a different pattern of affordability, especially in less accessible locations (Dewita et al. 2018). Several studies from European countries provide a similar result of the importance of incorporating transportation costs to reveal more appropriate measures of housing affordability. Transportation expenditure consists of three important variables which are vehicle ownership, vehicle usage, and public transit. Vehicle ownership is determined by the number of the vehicle, monthly payment of the vehicles, and the annual amount of insurance and tax. Vehicle usage is based on the amount of fuel consumption, monthly toll amount, parking fees, and cost and maintenance of the vehicles. Public transit is the total amount of monthly expenses on public transit.

\section{Methodology}

The quantitative research was utilized in this study whereby 68 questionnaires were distributed to respondents, and 65 questionnaires, that were answered without errors were collected to be analyzed. The area for questionnaire distribution focused on Perak Tengah among home buyers between 20 to 59 years old. The data obtained were analyzed through the Statistical Package for Social Science (SPSS) software.

\section{Conceptual framework}

In this present study, five independent variables (location, neighborhood, structural, financial, and transportation expenditure) and one dependent variable (housing affordability) were examined. The conceptual framework for this study was shown in Figure 1 showing the interrelationships between the independent variables and the dependent variable. 


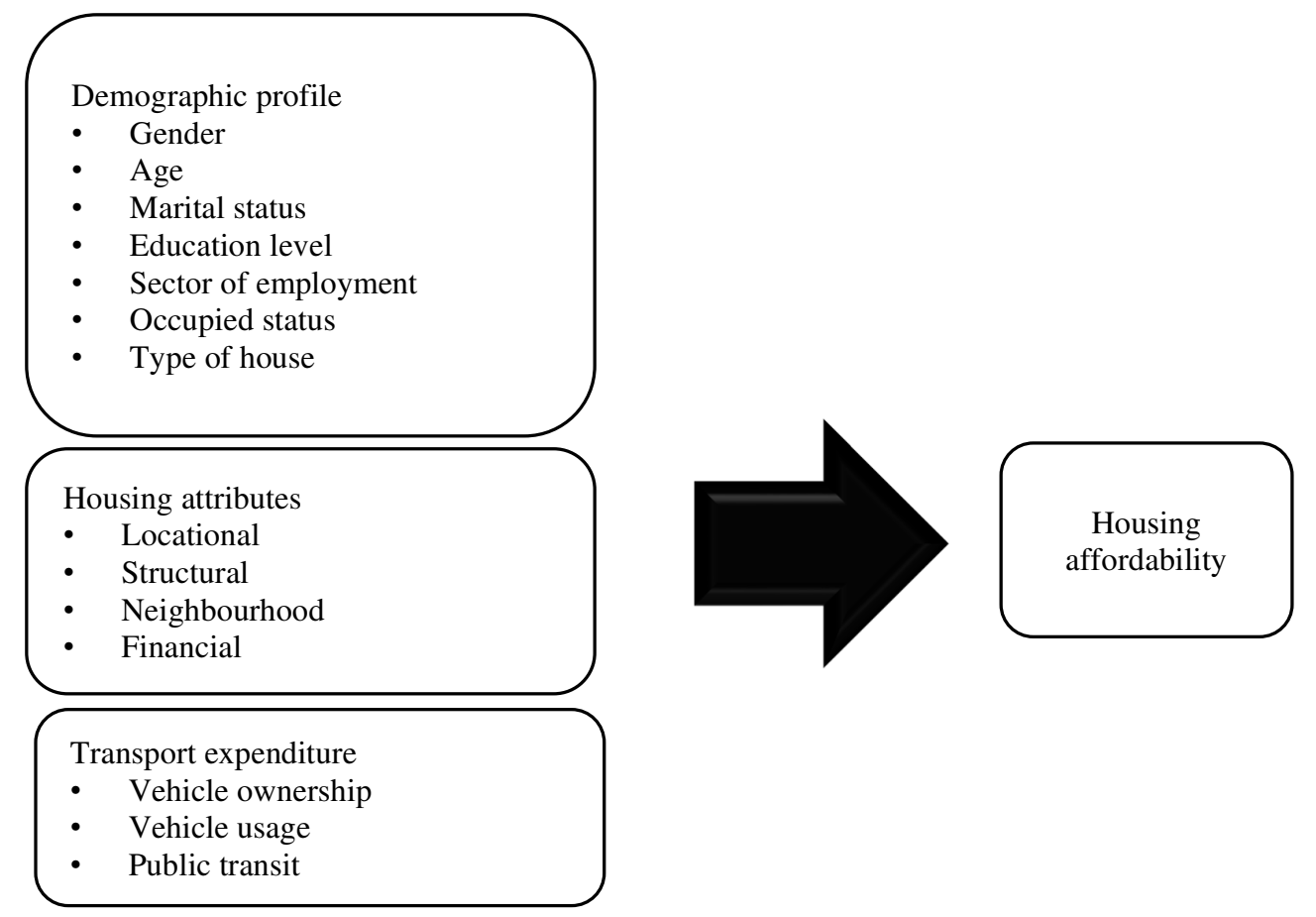

Figure 1: Conceptual framework

\section{Variables used in the study}

The measure of housing attributes are locational, neighborhood, structural and financial housing attributes. Six locational housing attributes were considered in this study; access to shopping facilities (Shopping), public transport facilities (Transport), health care facilities (Health care), leisure facilities (Leisure), school (School), and the workplace (Workplace). Neighborhood attributes included in the study were the level of neighborhood crime rate (Crime), gated neighborhood (Gated), neighborhood cleanliness (Cleanliness), neighborhood pollution (Pollution), and green surrounding neighborhood (Green). The size of a living area (Living), size of the kitchen (Kitchen), number of bathrooms (Bathroom), number of bedrooms (Bedroom), eco-friendly home (Eco), and built-up area (Built-up) were included to indicate structural attributes of the housing. Lastly, four financial housing attributes are included in this study, namely the price of the house (Price), amount of monthly repayment (Repayment), amount of interest rate (Interest), and duration of loan repayment (Duration). Transportation expenditure is divided into three variables which were vehicle ownership, vehicle usage, and public transit. Vehicle ownership is determined by the number of the vehicle, monthly payment of the vehicles, and the annual amount of insurance and tax. Vehicle usage is based on the amount of fuel consumption, monthly toll amount, and parking fees, and cost and maintenance of the vehicles. Public transit is the total amount of monthly expenses on public transit. The definition of independent variables used in the study is shown in Table 1. 
Table 1: Definition of independent variables in the study

\begin{tabular}{|c|c|c|}
\hline & Variables & Definition \\
\hline \multirow{6}{*}{ Locational attributes } & Shopping & 1 if access to shopping facilities is the main consideration when purchasing a house, 0 otherwise. \\
\hline & Transport & 1 if access to public transport facilities is the main consideration when purchasing a house, 0 otherwise. \\
\hline & Health care & 1 if access to health care facilities is the main consideration when purchasing a house, 0 otherwise. \\
\hline & Leisure & 1 if access to leisure facilities is the main consideration when purchasing a house, 0 otherwise. \\
\hline & School & 1 if the access to school is the main consideration when purchasing a house, 0 otherwise. \\
\hline & Workplace & 1 if access to the workplace is the main consideration when purchasing a house, 0 otherwise. \\
\hline \multirow{5}{*}{ Neighborhood attributes } & Crime & $\begin{array}{l}1 \text { if the level of crime rate in the neighborhood is the main consideration when purchasing a house, } 0 \\
\text { otherwise. }\end{array}$ \\
\hline & Gated & 1 if the presence of a gated neighborhood is the main consideration when purchasing a house, 0 otherwise. \\
\hline & Cleanliness & 1 if the cleanliness of the neighborhood is the main consideration when purchasing a house, 0 otherwise. \\
\hline & Pollution & $\begin{array}{l}1 \text { if the level of pollution in the neighborhood is the main consideration when purchasing a house, } 0 \\
\text { otherwise. }\end{array}$ \\
\hline & Green & $\begin{array}{l}1 \text { if the green surrounding of the neighborhood is the main consideration when purchasing a house, } 0 \\
\text { otherwise. }\end{array}$ \\
\hline \multirow{6}{*}{ Structural attributes } & Living & 1 if the size of the living area is the main consideration when purchasing a house, 0 otherwise. \\
\hline & Kitchen & 1 if the size of the kitchen is the main consideration when purchasing a house, 0 otherwise. \\
\hline & Bathroom & 1 if the number of the bathroom is the main consideration when purchasing a house, 0 otherwise. \\
\hline & Bedroom & 1 if the number of the bedroom is the main consideration when purchasing a house, 0 otherwise. \\
\hline & Eco & 1 if an eco-friendly home is the main consideration when purchasing a house, 0 otherwise. \\
\hline & Built-up & 1 if the built-up area of the house is the main consideration when purchasing a house, 0 otherwise. \\
\hline \multirow{4}{*}{ Financial attributes } & Price & 1 if the price of a house is the main consideration when purchasing a house, 0 otherwise. \\
\hline & Repayment & 1 if the amount of monthly repayment is the main consideration when purchasing a house, 0 otherwise. \\
\hline & Interest & 1 if the amount of interest rate of the loan is the main consideration when purchasing a house, 0 otherwise. \\
\hline & Duration & 1 if the duration of loan repayment is the main consideration when purchasing a house, 0 otherwise. \\
\hline \multirow{8}{*}{$\begin{array}{l}\text { Transportation } \\
\text { expenditures }\end{array}$} & \multirow{3}{*}{$\begin{array}{l}\text { Vehicle } \\
\text { ownership }\end{array}$} & Number of vehicles \\
\hline & & Monthly payment of the vehicles \\
\hline & & The annual amount of insurance and tax \\
\hline & \multirow[t]{4}{*}{ Vehicle usage } & The annual cost of fuel \\
\hline & & The monthly amount of toll \\
\hline & & The monthly amount of parking fees \\
\hline & & The annual cost of maintenance \\
\hline & Public transit & Amount of monthly expenses on public transport \\
\hline
\end{tabular}

\section{Levels of housing affordability}

The median multiple is a common measurement suggested by the World Bank and the United Nations which rates the affordability of housing by dividing the median house price and annual median household income. The affordability levels are categorized in four levels which are affordable, moderately unaffordable, seriously unaffordable, and severely unaffordable. The household is classified as affordable if the median multiple is lower than 3.0, while the household is classified as moderately unaffordable if the median multiple is between 3.1 to 4.0 , seriously unaffordable if the median multiple is between 4.1 to 5.0 and severely unaffordable if the median multiple is higher than 5.1 .

\section{Results and Discussions}

Table 2 shows the demographic profile of the respondents. The questionnaire was completed by 65 respondents, of which, 47 were females (72.3\%) and the remaining 18 were males $(27.7 \%)$ thus female respondents were slightly higher than male respondents. In terms of age, $33.8 \%$ of the respondents were of the age of 20-29, followed by the age of $30-39$ (30.8\%), the age of 50-59 (20.0\%), and the age of 40-49 (15.4\%), respectively. The majority of the respondents were married $(66.2 \%)$, while the single ones were $(32.3 \%)$ and widowed (1.5\%). A total of $43.1 \%$ of the respondents have a master's degree qualification followed by a bachelor's degree with $29.2 \%$ and a diploma qualification with $15.4 \%$. The public sector was the overwhelming majority of the respondents with $53.8 \%$, followed far behind by the private sector with $30.8 \%$, and self-employed respondents with $13.8 \%$. Most of the respondents were the owner of the house (52.3\%), several are tenants $(27.7 \%)$ and a few stayed at family homes or home share. $33.8 \%$ of the respondents stayed at a single-story terrace, followed by a double-storey terrace with 
$27.7 \%$, and respondents staying in an apartment or flat with $16.9 \%$.

Table 2: Profile of respondents

\begin{tabular}{|c|c|c|}
\hline Variables & Frequency & Percentage \\
\hline \multicolumn{3}{|c|}{ Gender } \\
\hline Male & 18 & 27.7 \\
\hline Female & 47 & 72.3 \\
\hline \multicolumn{3}{|c|}{ Age } \\
\hline $20-29$ & 22 & 33.8 \\
\hline $30-39$ & 20 & 30.8 \\
\hline $40-49$ & 10 & 15.4 \\
\hline $50-59$ & 13 & 20.0 \\
\hline \multicolumn{3}{|c|}{ Marital status } \\
\hline Married & 43 & 66.2 \\
\hline Single & 21 & 32.3 \\
\hline Widowed & 1 & 1.5 \\
\hline \multicolumn{3}{|c|}{ Education level } \\
\hline SPM & 5 & 7.7 \\
\hline Diploma & 10 & 15.4 \\
\hline Bachelor Degree & 19 & 29.2 \\
\hline Master's Degree & 28 & 43.1 \\
\hline Doctor of Philosophy & 3 & 4.6 \\
\hline \multicolumn{3}{|c|}{ Sector of employment } \\
\hline Private & 20 & 30.8 \\
\hline Public & 35 & 53.8 \\
\hline Self-employed & 9 & 13.8 \\
\hline Unemployed & 1 & 1.5 \\
\hline \multicolumn{3}{|c|}{ Occupied status } \\
\hline Owner & 34 & 52.3 \\
\hline Tenant & 18 & 27.7 \\
\hline Family home/share & 13 & 20.0 \\
\hline \multicolumn{3}{|c|}{ Type of house } \\
\hline Single storey terrace & 22 & 33.8 \\
\hline Double storey terrace & 18 & 27.7 \\
\hline Semi detached & 5 & 7.7 \\
\hline Bungalow & 4 & 6.2 \\
\hline $\begin{array}{l}\text { Condominium/Service } \\
\text { residence }\end{array}$ & 2 & 3.1 \\
\hline Flat/Apartment & 11 & 16.9 \\
\hline Others & 3 & 4.6 \\
\hline
\end{tabular}

\section{Regression Analysis}

There were two equations presented in the regression analysis. The first equation is solely based on the effect of housing attributes on housing affordability without taking into consideration transportation expenditure, whereas the second equations include transportation expenditure into the model. As shown in Table 3, the first and second equations explained about $77 \%$ and
$80 \%$ of the variation in housing affordability, respectively.

The results from both equations revealed that the access to shopping facilities and school were negatively significant to the housing affordability. Additionally, access to public transport, leisure facilities, and workplaces were positively significant to housing affordability. However, health care facilities were insignificant to housing 
affordability. Homebuyers in the study excluded health care facilities in determining the factors affecting housing affordability.

Since the crime rate in Malaysia increased significantly, homebuyers were slightly more concerned about their neighborhood condition. Based on estimations, results concluded that the level of crime rate, gated neighborhood, level of cleanliness, and green surrounding in the neighborhood were statistically significant and positively associated with housing affordability. This result is consistent with the findings of (Teck-Hong, 2012) who mentioned that neighborhood security is an important aspect when purchasing a house. Lastly, the level of pollution is not significant to the housing affordability in the first equation but positively significant after considering transportation expenditure in the equation.

For structural housing attributes, the size of the kitchen and the number of bedrooms were statistically significant and had a negative relationship with the housing affordability in both equations. This result is similar to Opoku and Abdul-Muhmin (2010), who mentioned that the private living space such as the number of bedrooms is the main consideration when purchasing a residential property. Besides, the number of bathrooms and built-up areas of the house were positively statistically significant towards housing affordability.
Nevertheless, the size of the living area and eco-friendly home did not have a significant relationship with housing affordability. It indicates that the size of the living area and eco-friendly home were not the main consideration when purchasing an affordable house.

Furthermore, homebuyers preferred houses that have good financial attributes. It shows that house prices, monthly repayment, interest rate, and duration of the loan were statistically significant to housing affordability. There was a positive relationship between monthly repayment and duration of loans with housing affordability in both equations. The finding is consistent with Mariadas et al. (2019a) that considered financial attributes as important factors in housing affordability.

After considering transportation expenditures in the model, the model is statistically significant. It shows that there was a significant relationship between housing attributes and transportation expenditures towards housing affordability. Additionally, the amount of insurance and tax and the annual fuel consumption were statistically significant to the housing affordability and negatively associated with it. The monthly payment, cost of the toll, cost of parking fees, maintenance, and public transport did not have a significant relationship with housing affordability. 
Table 3: Effect of housing attributes on housing affordability

\begin{tabular}{|c|c|c|c|c|c|c|c|c|}
\hline & \multicolumn{4}{|c|}{$\begin{array}{l}\text { Model } 1 \\
\end{array}$} & \multicolumn{4}{|c|}{ Model 2} \\
\hline & Coefficient & Std. Error & $\mathrm{T}$ & Sig. & Coefficient & Std. Error & $\mathrm{t}$ & Sig. \\
\hline Constant & 3.731 & 0.723 & 5.160 & $<0.001$ & 3.365 & 0.770 & 4.4368 & $<0.001$ \\
\hline Shopping & -0.521 & 0.173 & -3.018 & 0.004 & -0.403 & 0.188 & -2.147 & 0.039 \\
\hline Transport & 0.449 & 0.222 & 2.027 & 0.049 & 0.559 & 0.233 & 2.401 & 0.022 \\
\hline Health care & 0.240 & 0.167 & 1.434 & 0.159 & 0.167 & 0.159 & 1.050 & 0.301 \\
\hline Leisure & 0.358 & 0.146 & 2.457 & 0.018 & 0.408 & 0.150 & 2.724 & 0.010 \\
\hline School & -0.797 & 0.128 & -6.207 & $<0.001$ & -0.859 & 0.149 & -5.783 & $<0.001$ \\
\hline Workplace & 0.379 & 0.143 & 2.651 & 0.011 & 0.492 & 0.145 & 3.392 & 0.002 \\
\hline Crime & -0.790 & 0.215 & -3.670 & 0.001 & -0.612 & 0.217 & -2.823 & 0.008 \\
\hline Gated & -1.078 & 0.178 & -6.059 & $<0.001$ & -1.274 & 0.206 & -6.174 & $<0.001$ \\
\hline Cleanliness & -0.389 & 0.119 & -3.265 & 0.002 & -0.520 & 0.121 & -4.304 & $<0.001$ \\
\hline Pollution & 0.295 & 0.168 & 1.758 & 0.086 & 0.493 & 0.199 & 2.482 & 0.018 \\
\hline Green & -1.115 & 0.257 & -4.339 & $<0.001$ & -1.154 & 0.269 & -4.286 & $<0.001$ \\
\hline Living & 0.287 & 0.144 & 1.991 & 0.053 & 0.205 & 0.150 & 1.366 & 0.181 \\
\hline Kitchen & -0.615 & 0.230 & -2.676 & 0.011 & -0.480 & 0.228 & -2.103 & 0.043 \\
\hline Bathroom & 0.910 & 0.242 & 3.756 & 0.001 & 1.170 & 0.271 & 4.322 & $<0.001$ \\
\hline Bedroom & -0.862 & 0.189 & -4.549 & $<0.001$ & -0.969 & 0.231 & -4.194 & $<0.001$ \\
\hline Eco & -0.212 & 0.116 & -1.825 & 0.075 & -0.100 & 0.113 & -0.884 & 0.383 \\
\hline Built & 2.100 & 0.326 & 6.442 & $<0.001$ & 2.239 & 0.354 & 6.328 & $<0.001$ \\
\hline Price & -0.423 & 0.122 & -3.477 & 0.001 & -0.275 & 0.129 & -2.128 & 0.040 \\
\hline Repayment & 0.419 & 0.167 & 2.504 & 0.016 & 0.391 & 0.179 & 2.182 & 0.036 \\
\hline Interest & -0.568 & 0.145 & -3.907 & $<0.001$ & -0.736 & 0.159 & -4.633 & $<0.001$ \\
\hline Duration & 0.350 & 0.125 & 2.802 & 0.008 & 0.290 & 0.140 & 2.076 & 0.045 \\
\hline Number of vehicles & & & & & -0.029 & 0.124 & -0.234 & 0.817 \\
\hline Monthly payment & & & & & 0.0001 & 0.00009 & 1.073 & 0.291 \\
\hline Insurance and tax & & & & & -0.0001 & 0.00006 & -2.284 & 0.029 \\
\hline Fuel & & & & & -0.0001 & 0.00003 & -2.276 & 0.040 \\
\hline Toll & & & & & 0.0002 & 0.00024 & 0.967 & 0.340 \\
\hline Parking fees & & & & & -0.000 & 0.00024 & -0.789 & 0.436 \\
\hline Maintenance & & & & & 0.0001 & 0.00004 & 1.769 & 0.086 \\
\hline \multirow[t]{4}{*}{ Public } & & & & & -0.0002 & 0.00086 & -0.185 & 0.854 \\
\hline & \multicolumn{4}{|c|}{ F-statistics $=11.408(<0.001)$} & \multicolumn{4}{|c|}{ F-statistics $=10.277(<0.001)$} \\
\hline & \multirow{2}{*}{\multicolumn{4}{|c|}{$\mathrm{R}^{2}=0.848$}} & \multicolumn{4}{|c|}{$R^{2}=0.895$} \\
\hline & & & \multicolumn{2}{|c|}{ Adjusted $\mathrm{R}^{2}=0.773$} & \multicolumn{4}{|c|}{ Adjusted $\mathrm{R}^{2}=0.808$} \\
\hline
\end{tabular}

*Significance at 0.05

\section{Conclusions}

There appear to be differences between the current and previous conceptual measurement of housing affordability due to the exclusion of transportation expenditure. This study also relevant to the housing developers because it provides information for improving the housing delivery system by including transportation expenditure. To ensure the success of affordable housing schemes, developers should be aware of homebuyers' interests by determining the factors related to homeownership priorities. The result of this study showed that variables associated with locational attributes such as access to shopping, public transport, leisure, school, and workplace were found to be significant to housing affordability. Homebuyers are not only paying attention to the quality of housing but they are also concerned about the good and safe environment. Homebuyers prefer gated communities and guarded neighborhoods. Besides, the financial factor is found to be an important consideration when purchasing a residential property. Homebuyers are more concerned about the house price, the interest rate, the amount of monthly payment, and the duration of the loan when purchasing an affordable house. Transportation expenditures such as the amount of insurance and tax and consumption of fuel were statistically significant to housing affordability. Given the significant factors of transportation expenditure, local and state governments are encouraged to consider transportation expenditures when planning for affordable housing. This paper supported the argument that incorporating transportation costs into affordability measures reveals true housing affordability. Thus, transportation expenditure should be a part of the definition of affordable housing as it influences household expenditure.

\section{Acknowledgment}

The authors would like to express their sincere appreciation to Universiti Teknologi 
MARA for granting financial assistance to undertake this study.

\section{References}

- Chia, J., Harun, A., Wahid, A., Kassim, M., Martin, D. and Kepal, N. (2016) 'Understanding Factors That Influence House Purchase Intention Among Consumers in Kota Kinabalu: An Application of Buyer Behavior Model Theory', Journal of Technology Management and Business, 3(2).

- Daly, J., Gronow, S., Jenkins, D. and Plimmer, F. (2003) 'Consumer behaviour in the valuation of residential property: A comparative study in the UK, Ireland and Australia', Property Management, 21(5), pp. 295-314.

- Dewita, Y., Yen, B. T. H. and Burke, M. (2018) 'The effect of transport cost on housing affordability: Experiences from the Bandung Metropolitan Area, Indonesia', Land Use Policy, 79, pp. 507519.

- $\quad$ Gan, Q., and Hill, R. J. (2009) 'Measuring housing affordability: Looking Beyond the median', Journal of Housing Economics, 18, pp. 115-125.

- Hurtubia, R., Gallay, O. and Bierlaire, M. (2010) 'Attributes of households, locations, and real estate markets for land use modeling', SustainCity Deliverable, 2(1).

- Kauko, T. (2007) 'An analysis of housing location attributes in the inner city of Budapest, Hungary, using expert judgments', International Journal of Strategic Property Management, 11, pp. 209-225.

- Li, J., Xu, Y. and Chiang, Y. H. (2014) 'Property Prices and Housing Affordability in China: A Regional Comparison', Journal of Comparative Asian Development, 13(3), pp. 405-435.

- Mariadas, P. A., Abdullah, H. and Abdullah, N. (2019a) 'Factors Affecting Purchasing Decision of Houses in the Urban Residential Property Market in Klang Valley, Malaysia', Journal of Social Sciences and Humanities, 16(4), pp. 1-9.

- Mariadas, P. A., Abdullah, H. and Abdullah, N. (2019b) 'Factors influencing the first home purchase decision of middle-income earners in Selangor, Malaysia', Journal of Social Sciences and Humanities, 16(1), pp. 111.

- Mattingly, K. and Morrissey, J. (2014) 'Housing and transport expenditure: Socio-spatial indicators of affordability in Auckland', Cities, 38, pp. 69-83.

- Mostafa, A., Wong, F. W. and Hui, C. M. E. (2006) 'Relationship between housing affordability and economic development in Mainland China - Case of Shanghai', Journal of Urban Planning and Development, 132, pp. 62-70.

- Mulliner, E. and Maliene, V. (2012) 'What attributes determine housing affordability?', International Journal of Social, Behavioral, Educational, Economic, Business and Industrial Engineering, 6(7), pp. 1833-1838.

- Natasha, I. and Hassan, Z. (2015) 'Factors that influencing property investment decisions among Employees in Felcra Bhd', International Journal of Accounting \& Business Management, 3(2), pp. 160-177.

- Olanrewaju, A. L., Lim, X. Y., Tan, S. Y., Lee, J. E. and Adnan, H. (2018) 'Factors affecting housing prices in Malaysia: Analysis of the supply side', Journal of the Malaysian Institute of Planners, 16(2), pp. 225-235.

- Opoku, R. A. and Abdul-Muhmin, A. G. (2010) 'Housing preferences and attribute importance among lowincome consumers in Saudi Arabia', Habitat International, 34, pp. 219-227.

- Sabri, S., Ludin, A. N. M. and Johar, F. (2013) 'Assessment of neighborhood affordability based on housing and transportation costs in Kuala Lumpur, Malaysia', Planning Malaysia, pp. 75100.

- Sean, S. L., and Hong, T. T. (2014) 'Factors affecting the purchase decision of investors in the residential property market in Malaysia', Journal of Surveying, Construction \& Property, pp. 1-13.

- $\quad$ Suhaida, M. S., Tawil, N. M., Hamzah, N., Che-Ani, A. I., Basri, H. and Yuzainee, M. Y. (2011) 'Housing affordability: A conceptual overview for house price index', Procedia Engineering, pp. 346353. 
- Sundrani, D. M. (2018) 'Factors influencing the home-purchase decision of buyers of different types of apartments in India', International Journal of Housing Markets and Analysis, 11(4), pp. 609-631.

- Tan, T. H. and Cheah, Y. Y. (2013) 'Locational, Neighborhood, Structural and Socio-Cultural Attributes of Housing In Homeownership Decisions', Journal of Chemical Information and Modeling, 53(9), pp. 1689-1699.

- Teck-Hong, T. (2011) 'Neighborhood preferences of house buyers: the case of Klang Valley, Malaysia', International Journal of Housing Markets and Analysis, 4(1), pp. 58-69.

- Teck-Hong, T. (2012) 'Meeting firsttime buyers' housing needs and preferences in greater Kuala Lumpur', Cities, 29, pp. 389-396.

- Thaker, H. M. T., and Sakaran, K. C. (2016) 'Prioritisation of key attributes influencing the decision to purchase a residential property in Malaysia: An analytic hierarchy process (AHP) approach', International Journal of Housing, 9(4).
- Thanaraju, P., Khan, P. A. M., Juhari, N. H., Sivanathan, S. and Khair, N. M. (2019) 'Factors affecting the housing preferences of homebuyers in Kuala Lumpur', Journal of the Malaysian Institute of Planners, 17(1), pp. 138148.

- Yusoff, Z. M., Adnan, N. A. and Rasam, R. A. (2014) '[H+T] Affordability Index for Low-Cost Housing LocationDistribution Procedure', in Arte-Polis 5 Intl Conference - Reflections on Creativity: Public Engagement and the Making of Place.

- Zainon, N., Mohd-Rahim, F. A., Sulaiman, S., Abd-Karim, S. B. and Hamzah, A. (2017) 'Factors affecting the demand of affordable housing among the middleincome groups in Klang Valley Malaysia', Journal of Design and Built Environment, pp. 1-10.

- Zrobek, S., Trojanek, M., ZrobekSokolnik, A. and Trojanek, R. (2015) 'The influence of environmental factors on property buyers' choice of residential location in Poland', Journal of International Studies, 8(3), pp. 164174. 